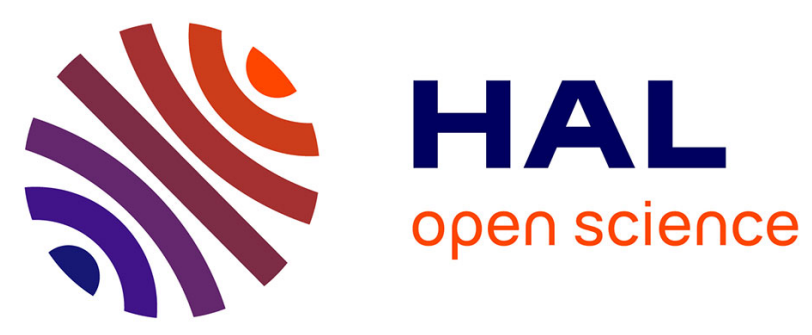

\title{
Contributions of experiment designs in photodynamic therapy: photosensitizer design, treatment analysis and optimization.
}

Thierry Bastogne, Loraine Tirand, Julien Gravier, Denise Bechet, Vincent Morosini, Marlène Pernot, Céline Frochot, Alain Richard, François Guillemin, Muriel Barberi-Heyob

\section{To cite this version:}

Thierry Bastogne, Loraine Tirand, Julien Gravier, Denise Bechet, Vincent Morosini, et al.. Contributions of experiment designs in photodynamic therapy: photosensitizer design, treatment analysis and optimization.. 13th World Congress of the International Photodynamic Association, IPA 2011, May 2011, Innsbruck, Austria. pp.CDROM. hal-00597950

\section{HAL Id: hal-00597950 https://hal.science/hal-00597950}

Submitted on 2 Jun 2011

HAL is a multi-disciplinary open access archive for the deposit and dissemination of scientific research documents, whether they are published or not. The documents may come from teaching and research institutions in France or abroad, or from public or private research centers.
L'archive ouverte pluridisciplinaire HAL, est destinée au dépôt et à la diffusion de documents scientifiques de niveau recherche, publiés ou non, émanant des établissements d'enseignement et de recherche français ou étrangers, des laboratoires publics ou privés. 


\title{
Contributions of experiment designs in photodynamic therapy: photosensitizer design, treatment analysis and optimization.
}

\author{
Thierry Bastogne ${ }^{1,2}$, L. Tirand ${ }^{1}$, J. Gravier ${ }^{5}$, D. Bechet ${ }^{1}$, V. Morosini ${ }^{1}$, M. Pernot ${ }^{1}$, C. Frochot ${ }^{3,4}$, \\ A. Richard ${ }^{1}$, F. Guillemin ${ }^{1}$, M. Barberi-Heyob ${ }^{1,4}$ \\ 1 - CRAN, Nancy-Université, CNRS UMR 7039, Centre Alexis Vautrin, 54511 Vandœuvre-lès-Nancy, \\ France \\ 2 - INRIA BIGS (Blology, Genetics and Statistics), 54506 Vandœuvre-lès-Nancy, France \\ 3 - LRGP, Nancy-Université, CNRS UPR 3349, 1 rue Grandville, 54000 Nancy, France \\ 4 - GdR CNRS, PHOTOMED 3049 « Médicaments Photoactivables - Photochimiothérapie » \\ 5 - CEA LETI, 17 rue des Martyrs, 38054 Grenoble, France
}

Email: thierry.bastogne@cran.uhp-nancy.fr

\section{Introduction}

One of the difficulties in the development of the photodynamic therapy (PDT) is inherent to the multidisciplinary feature of this treatment gathering mainly clinicians, physicists, biologists, and chemists. Another issue is the great number of biophysical and biochemical parameters involved in the design of new photosensitizers as well as in the in vivo application of this treatment. We present a global development approach based on the methodology and tools of experimental design. Three study cases are developed to assess to potential relevance of such an empirical model-based approach for the development of PDT.

\section{Methods \& Results}

In a first study, an in vitro screening experimental design was carried out. The addressed question dealt with the determination of influent factors on the phototoxicity of a new photosensitizer based on quantum dots. Five factors were examined: the nature of quantum dots, the excitation light wavelength, the incubation time with cells, the photoactivable compound concentration and the fluence level. Relevance of each factor was finally estimated and compared to identify the significant parameters. In comparison with a typical factorial design, the total number of experiments ( 42 trials) was divided by 5 .

In a second study, an in vivo factorial experimental design was applied to detect potential synergic effects between four therapeutic factors: the phenotype of the cancer cell line, the food type, the nature of photosensitizer and the post-injection time, on the in vivo selectivity (cancer/normal tissue) of the tested photosensitizers. Results particularly pointed out the presence of a statistically significant synergic effect between these four factors and provided the optimal modalities to maximize the response in term of tumor-to-normal tissue ratio.

In a third study, a Doehlert experimental design associated with a response surface model was used to determine the in vivo PDT modalities (photosensitizer concentration, irradiance and fluence) to both minimize the post-treatment growth rate of the tumor and maximize its growth delay. Only 13 experimental conditions were tested and the relevance of the optimized condition was corroborated by in vivo validation experiments.

\section{Conclusion}

These studies have confirmed the applicability and attractive contributions of experimental design techniques in the development and determination of optimal modalities of new photosensitizers in PDT. Their main advantages are to a priori organize experiments according to specific questions while minimizing the experimental cost and controlling as much as possible the experimental uncertainty. 